\title{
Identification of Apoptotic Cells by Means of Lectin Histochemistry: State of the Art Review
}

\section{Vicente Seco-Rovira, Esther Beltrán-Frutos, Concepción Ferrer, Jesús Martínez-Hernández and Luis M. Pastor ${ }^{*}$}

Department of Cell Biology and Histology, Medical School, IMIB-Arrixaca, Regional Campus of International Excellence "Campus Mare Nostrum", University of Murcia, Campus de Espinardo, 30100, Spain

"Corresponding author: Luis M. Pastor, Department of Cell Biology and Histology, Medical School, IMIB-Arrixaca, Regional Campus of International Excellence "Campus Mare Nostrum", University of Murcia, Campus de Espinardo, 30100, Spain, Tel: +34 868883949 ; Fax: +34 868 88 41 50; E-mail: bioetica@um.es

Rec date: Jan 20, 2015, Acc date: Feb 10, 2015, Pub date: Feb 12, 2015

Copyright: (c) 2015 Pastor LM, et al. This is an open-access article distributed under the terms of the Creative Commons Attribution License, which permits unrestricted use, distribution, and reproduction in any medium, provided the original author and source are credited.

\begin{abstract}
Apoptosis is a cellular phenomenon of great importance in the cellular homeostasis of tissues and organs. For many years diverse techniques have been developed for the identification and differentiation of normal and apoptotic cells, but only in cells isolated in cultures as in histology sections. These techniques are based on the modifications that cells suffer during the process of apoptosis. One of these changes is linked with modifications of glycoconjugates in the glycocalix of cells, which allows the use of lectins for identification of these apoptotic cells. In this review, we first present the data obtained to date with this approach for the detection of apoptotic cells with lectins, both using flow cytometry and, especially, cytochemical methods. Secondly we comment on the results obtained in the detection of apoptotic cells with classical lectin histochemistry using histological sections of the seminiferous epithelium. These results open the possibility of using lectins in normal and pathological organs as a tool to identify "in situ" apoptotic cells both in the initial and late phases of apoptosis although further studies are needed in other organs to determine their usefulness and effectiveness over others identification techniques of "in situ" apoptosis.
\end{abstract}

Keywords: Lectins; Apoptosis; Histochemistry; Glycocongugates

\section{Introduction}

Controlling the number of cells within a tissue is performed by the proliferation and cell death, both involved in the maintenance of the number of cells within a tissue. Consequently, the cell cycle includes both the cell proliferation cycle and programmed cell death (apoptosis) [1,2].

Morphologically, apoptosis can be visualized microscopically. Some changes can be observed with the light microscope, sometimes using specific staining, and other changes can only be detected by transmission electron microscopy. Unlike necrosis, early changes involving nuclear chromatin condensation around the nuclear perimeter depend on the context, the separation of neighboring cells and the connections to the extracellular matrix. Plasma membrane protrusions or "blebs" appear and the completely condensed nucleus is divided into a number of fragments [3]. Intact organelles are generally observed, although both endoplasmic reticulum dilatation and ribosome losses have been described. Sometimes cytoplasmic vacuoles have been described [4]. Afterwards, the cells disintegrate into apoptotic bodies, which may contain any portion of the cellular material. Finally these apoptotic bodies are phagocytized by neighboring cells. Although this type of cell death was initially called "shrinkage necrosis" [5] since it plays a complementary role to mitosis in the regulation of cell populations in various tissues, the term apoptosis was subsequently proposed [4].

The regulation of apoptosis is as complex as the regulation of proliferation. The differentiated cells of multicellular organisms show the ability to bring about their own death through the activation of an internally encoded suicide program. When this program is activated, a form of cell death, called apoptosis, or programmed cell death is initiated [6] a process in which several proteases called caspases are involved. Caspases are proteolytic cytosolic enzymes, more specifically cysteine proteases related to its ability to break peptide bonds after aspartic acid residue. The caspases contained in all cells are present as inactive precursors called procaspases. These pro-enzymes are normally processed by autoproteolysis or by intervention of other proteases [7] been called caspase cascade. Functionally, it can be talked of two types of caspases: initiators and executors [8]. Initiator caspases (Caspases 2, 8, 9 and 10) are usually activated as a result of events occurring in the cell membrane [9], while executors caspases (caspase 3,6 and 7) which are activated later than initiator caspases, are responsible for the proteolytic cleavage of important molecules (PAK-2, or DNA "fragmentation factor" (DFF)).

The important role of caspases in the apoptotic process is evident. Thus, for example, the effect of caspase- 6 involves the disintegration of the nucleus by the "splicing" of the structural protein of the nuclear membrane: lamin A [10]. There are three main mechanisms that can lead to caspase activation: 1) ligand-receptor binding with the activation of caspase-8; 2) a mitochondrial activation mechanism of caspase-9; and 3) a process involving the endoplasmic reticulum and activation of caspase-12 [11].

As mentioned above, a balance of cell proliferation and apoptosis is critical for the growth and remodeling of tissues, both during development and during adult life, and is essential for the maintenance of tissue homeostasis [12], This balance is present both in very different physiological processes, e.g. follicular atresia [13], germ cell apoptosis $[2,14]$ as well as in pathological conditions including cancer [6], autoimmune and neurodegenerative disorders (Alzheimer and Parkinson's diseases) and viral infections (AIDS) [15]. 


\section{Apoptosis and Glycoconjugates}

During the process of apoptosis, changes in glycoconjugates (sugar residues of oligosaccharides $\mathrm{N}$ - or O-glycosidically linked to proteins, (Glyc)) have been observed in various cell types. These Glyc, either alone or complexed with glycan-binding proteins, can deliver intracellular signals or control extracellular processes that promote the initiation, execution and resolution of cell death programs. In this way, glycans and glycan-binding proteins are essential components of the cell death machinery in physiological and pathological settings. Their participation in apoptosis appears to be linked to several phenomena: a) modifications of Glyc exposed by death receptors; b) cross-talk between lectins and death receptors in the initiation of cell death (galectins); c) glycosylation-related molecules participating as integral components of the autophagy and apoptosis machineries d) finally, endogenous lectins and Glyc can serve as 'find me', 'keep out' and 'eat me' signals in the resolution of apoptosis via phagocytosis [16].

Lectins are proteins of plant, fungal, microbial and animal origin that specifically recognize the sugar residues of glycoproteins and glycolipids, showing a characteristic binding pattern which defines the glycoconjugates of organs or tissues studied [17]. Their molecular structure, carbohydrate-binding properties and biological activities have been covered in detail in several reviews [18-25]. These proteins have been widely used for the detection of carbohydrate in various tissues and organs, e.g., the respiratory system [26-29], digestive system [30-32], and male [33-37] and female [38-40] reproductive systems, and in diverse pathological situations [41]. The use of lectins for the histochemical detection of glycans in tissue sections (lectin histochemistry) is an area of important applications for these molecules. The interaction of lectins with their binding sites on cell surfaces or in sections of cells and tissues can be visualized using different markers commonly used in immunohistochemistry [25]. "Hence, lectins can be directly labeled with various fluorochromes or enzymes for use in light microscopy and with peroxidase, ferritin or colloidal gold for electron microscopy. As antibodies, lectins can be covalently modified by haptens such as biotin and digoxigenin, and subsequently detected by streptavidin or antidigoxigenin antibodies, respectively, either complexed with gold or conjugated to horseradishperoxidase" [25]. The lectins application in different tissues showed a characteristic pattern of affinity for lectins and a characterization of principal carbohydrates in the cells of specific tissues or organs. Changes in these patterns can be studied in physiological or pathological situations, obtaining not only biological information of this process but also specific markers of the same [25].

In relation with apoptosis, the lectin histochemistry was proposal some years ago as a method for the histological identification of apoptotic cells [42]. This minireview presents evidence for this and also some of the results that we have obtained recently regarding the detection of apoptotic cells in the seminiferous epithelium.

\section{Identification of Apoptotic Cells by Lectins}

Nowadays, a wide variety of imaging and histochemical techniques are available for the investigation of apoptosis, both light and electron microscopy. Inmmunohistochemical detection of the proteins involved in the apoptotic pathways, ultrastructural morphology studies, considered the "gold standard" for the identification of apoptotic cells or flow-cytometry are commonly used, although the detection of apoptosis by histochemical light microscopy is routinely used [42]. In this area, too, the TUNEL assay [terminal deoxynucleotidyl transferase (TdT)-mediated dUTP in situ nick end labeling] is much utilized. This test detects free $3-\mathrm{OH}$ terminals of both single- and double-strand DNA breaks. Some markers for apoptotic cells require the use of live cells. For instance, early in the apoptotic cascade of events, phosphatidyl serine residues Xip from the internal to external side of the cells' plasma membrane are modified. Accordingly, Annexin V, which binds specifically to phosphatidyl serine residues, has been used as a specific probe for apoptosis [43].

Bilyy et al. $[44,45]$ and Bilyy and Stoika $[46,47]$ identified plasma membrane glycoconjugates as indicators of apoptosis. Other authors have also used lectins to identify cells in late apoptosis [48-50]. Bilyy detected an increase in the expression of $\alpha$-D-mannose- and $\beta$-Dgalactose-containing glycoproteins in the plasma membrane in response to apoptotic signals and a decrease in the level of $\alpha 2,3$-sialic acid-containing glycoproteins. These studies were realized in smears of cultured cells and not in organs or tissues. The use of lectins for carbohydrate identification on the cell surface was successfully assayed not only for apoptotic cell detection, but also for apoptotic cell isolation. A lectin cytochemical study of normal and apoptotic murine leukemia cells of the L1210 line was made in 2003. Horseradish peroxidase-labeled Laburnum anagyroides bark agglutinin (LABA), Phaseolus vulgaris agglutinin (PHA), Pisum sativum lectin (PSL), Ricinus communis agglutinin (RCA-120; $120 \mathrm{kDa}$ ), Solanum tuberosum agglutinin (STA), Triticum vulgaris lectin (WGA, wheat germ agglutinin), Viscum album agglutinin (VAA), Canavalia ensiformis lectin (Concanavalin A), and Helix pomatia lectin (HPA) were used. The authors compare specific glycoprotein expressions "in normal and apoptotic murine leukemia cells of the L1210 sensitive (L1210) and resistant (L1210R) lines to apoptosis induction by cisplatin". The results showed "a significantly increased binding of $\alpha$ $D$-mannose-specific PSL lectin $(\mathrm{P}<0.01)$ and $\beta$-D-galactose-specific RCA-120 lectin $(\mathrm{P}<0.001)$ by the apoptotic cells of the L1210 and L1210R lines than in intact cells" [46] further the "binding was shown to be specific because it was blocked by the corresponding inhibitory sugars" [46]. In another study, the same authors showed that these changes in glycoprotein expression can be common for apoptotic cells of different origin and for various ways of apoptosis induction. They demonstrated that the strong expression of plasma membrane glycoproteins rich in $\alpha-D$-mannose and $\beta$-D-galactose did not depend neither the type of cell line and its tissue origin nor the nature of the apoptotic-inducing agent. They also found that an increase in membrane glycoprotein expression was dependent on the concentration of apoptosis-inducing agent and was time-dependent [44]. With respect to the use of lectins for apoptotic cell separation the authors showed a procedure with PSL-lectin-affinity for the isolation of apoptotic cells from a population mixed with normal cells. This process occurs at much lower lectin dilutions in the apoptotic cells than in the non-apoptotic cells. They concluded that " $\alpha-D$-mannoseand $\beta$-D-galactose-containing glycoproteins can be used for the cytochemical detection, study and isolation of apoptotic cells" [44].

This investigation group used the lectins to study changes in surface Glyc expression in peripheral blood lymphocytes (PBL) of normal healthy donors (NHD) and patients with rheumatoid arthritis (RA), measured by cell agglutination with the galactose-specific VAA lectin and by lectin-cytochemical analysis. In parallel, these changes in apoptotic incidence were evaluated by the detection of cells with subG1 DNA content. The data revealed an increased level of apoptosis in lymphocytes of RA patients, with high cell surface Glyc expression and with an increased number of cells exposing galactose-rich Glyc. The 
authors concluded that cell surface Glyc can be used for the detection of apoptotic cells in RA and other autoimmune disorders [51].

The subsequent investigations of this group looked at the elimination by phagocytosis of apoptotic cells with the changes of Glyc in plasmatic membrane cells. These changes in the glycocalyx could either directly mediate cellular engulfment or enhance phagocytosis through cooperation with other engulfment signals. Thus, they found that apoptotic cells release distinct types of membranous vesicles, which show "eat-me" signals on their surfaces. Those, vesicles that were originated from endoplasmic reticulum, exhibit immature (highmannose) glycoepitopes and are preferentially phagocytized by macrophages. In contrast, the plasma membrane-derived apoptotic bodies and apoptotic blebs exhibit increased sialidase activity on their surfaces, which presumably results from caspase-3-dependent activation of plasma membrane-associated neuraaminidase-1 (Neu1). In conclusion, they propose a mechanism that involves alterations of the glycocalyx during apoptosis and provide evidence that the reduced sialylation of cells undergoing apoptosis may be caused by both surface exposure of immature ER-derived glycoproteins and surfacebound sialidase activity cleaving mature glycoproteins in situ. ERderived blebs are prioritized by macrophages during apoptotic cell clearance. They also demonstrate that apoptotic cells, which are endowed with an increased surface sialidase activity, desialylate neighboring viable cells that are phagocytized by macrophages [52].

\begin{tabular}{|c|c|c|c|c|}
\hline Authors & Cell type & Lectin and sugar identified & Technique & Reference \\
\hline Bilyy and Stoika & Murine Leukemia cell of L1210 line & $\begin{array}{l}\text { PSL ( } \alpha-m a n n o s e) \\
\text { RCA-120 ( } \beta \text { - -D-galactose) }\end{array}$ & $\begin{array}{l}\text { Lectin cytochemical } \\
\text { study }\end{array}$ & 46 \\
\hline Bilyy, et al. & $\begin{array}{l}\text { Murine Leukemia cell of L1210 line } \\
\text { Murine fibroblast of L929 cell line } \\
\text { Human Adenocarcinoma MCF-7 line wild type (wt) } \\
\text { Resistant to doxorubicin (DOX/R) human leukemia } \\
\text { Jurkat cell lines }\end{array}$ & $\begin{array}{l}\text { PSL ( } \alpha-m a n o n o s e) \\
\text { RCA-120 ( } \beta \text {-D-galactose) }\end{array}$ & $\begin{array}{l}\text { Lectin } \quad \text { cytochemical } \\
\text { study }\end{array}$ & 44 \\
\hline Bilyy and Stoika & $\begin{array}{l}\text { In vitro: murine and human cell lines } \\
\text { In vivo: Lymphocytes, murine splenocytes inoculated } \\
\text { to mouse treated with dexamethasone, murine } \\
\text { leukemia L1210 cells inoculated to mouse treated with } \\
\text { doxoribicin }\end{array}$ & $\begin{array}{l}\text { PSL, PMRL, GNA, NPL ( } \alpha \text {-D-mannose) } \\
\text { RCA, VAA.( } \beta \text {-D-galactose) }\end{array}$ & $\begin{array}{l}\text { Lectin } \quad \text { cytochemical } \\
\text { study }\end{array}$ & 47 \\
\hline Bilyy, et al. & $\begin{array}{l}\text { Peripheral blood lymphocytes (PBL) of normal donors } \\
\text { and reumatoid artritis patients. }\end{array}$ & VAA ( $\beta$-D-galactose) & $\begin{array}{l}\text { Lectin } \quad \text { cytochemical } \\
\text { study }\end{array}$ & 51 \\
\hline Batisse, et al. & U-937 cells & MAA and SNA (Sialic acids) & $\begin{array}{l}\text { Flow Cytometry } \\
\text { Lectin Blot }\end{array}$ & 48 \\
\hline Franz, et al. & $\begin{array}{l}\text { Peripheral blood lymphocyte } \\
\text { Nonadherent hematopoetic cell lines Jurkat } \\
\text { Raji } \\
\text { U-937 cells }\end{array}$ & $\begin{array}{l}\text { GSL II (terminal- } \alpha, \beta-G I c N A c), N P n \text { ( } \alpha- \\
\text { D-mannosylresidues), UEA-I (L- } \\
\text { Fucose) }\end{array}$ & $\begin{array}{l}\text { Lectin-cytochemical } \\
\text { analysis; Flow cytometry }\end{array}$ & 49 \\
\hline Malagolini, et al. & $\begin{array}{l}\text { Colon cancer cell lines SW48 and SW948 } \\
\text { Cell lines HT29 (colon),MCF7 (breast) } \\
\text { Panc1 (pancreas), HT1376 (bladder) }\end{array}$ & SNA (Neu5Ac a 2,6-Gal) & $\begin{array}{l}\text { Lectin Cytochemical } \\
\text { analysis } \\
\text { Lectin Blot }\end{array}$ & 50 \\
\hline Azuma, et al. & $\begin{array}{l}\text { Human colon adenocarcinoma cell line (HT-29); } \\
\text { human monocytic cell line (THP-1) }\end{array}$ & $\begin{array}{l}\text { RCA (( } \beta \text {-D-galactose), LFA (Sialic } \\
\text { acid), AAL (fucose linked }(\alpha-1,6) \text { to } N- \\
\text { acetylglucosamine), Con-A } \\
\text { mannose) }\end{array}$ & Flow Cytometry & 53 \\
\hline
\end{tabular}

Table 1: Bibliography related with the identification of apoptotic somatic cells using lectins.

Other groups, too, have used lectins to identify apoptotic cells. In 2000, a lectin-based approach for detecting apoptotic cells in flow cytometry detected a changed pattern of glycoproteins of the plasma membrane during apoptosis using the FITC-labeled lectin Narcissus pseudonarcissus (NPn) [53]. In 2004, application of the same using a flow cytometric procedure showed that apoptosis is associated with a marked decrease in cell surface sialylation. This investigation was realized using the sialic acid-specific lectins, Maackia amurensis agglutinin (MAA) and Sambucus nigra agglutinin (SNA). These observations were corroborated by lectin blotting analysis with the same lectins [48]. Also using flow cytometry, two years later Franz et al. [49], showed that the lectins Griffonia simplificolia II (GSL II), Narcissus pseudonarcissus (NPn), and Ulex europaeus I (UEA I) have no cytotoxic activity and bind preferentially to dying cells. "Primary and secondary necrotic cells displayed an equal staining intensity, which was substantially higher than for apoptotic cells. The kinetic of the lectin staining correlated with the increase in subG1-DNA, GSL II, $\mathrm{NPn}$, and UEA I are specific for $\mathrm{N}$-acetylglucosamine, mannose, and fucose, respectively"[49]. "According to their binding specificity, the authors concluded that $\mathrm{N}$-acetylglucosamine-, mannose-, and fucosecontaining epitopes are increasingly exposed on cells undergoing apoptosis", [49]. 
With respect to identifying glycoproteins with changed exposure during apoptosis, such proteins have been isolated from plasma membrane by means of lectin-affinity chromatography and high resolution electrophoresis in gradient PAAG-SDS electrophoresis. These glycoproteins were integral and peripheral components of the plasma membrane. "The MALDI-TOF study of [45], revealed that they participate in cell signaling (specific G-protein beta-subunit-like protein) and apoptosis signaling pathways [54] as well as in cytoskeleton functioning (dynein heavy chain, microtubule-actin cross-linking factor, dystonin isoform $\beta$ )" [47]. Table 1 summarize the articles most important commented.

In synthesis, the use of lectins to identify changes in the plasmatic membrane Glyc is a recent development. However, such investigations have used smears of isolated cells or flow cytometry and focused on the glycocalyx of apoptotic cells with a special attention paid to changes with the apoptotic cell clearance. To date no lectin histochemical research in sections of organs and tissues to identify apoptotic cells in diverse phases of apoptosis has been performed.

\section{Apoptosis Identification in Seminiferous Epithelium through Lectin Histochemistry}

Recently our investigation group has used lectin-binding as a tool for the identification of apoptotic cells in seminiferous epithelium of histological sections of hamster testes [55]. In normal conditions, apoptosis in the seminiferous epithelium mainly occurs in the spermatogonia and spermatocytes and, to a lesser degree, in early spermatids [56] thus regulating the amount of germ cells that are supported by the Sertoli cells [57]. This study was realized during a process of testicular regression due to the exposure of animals to short-photoperiod. An extensive battery of Horseradish peroxidase (HRP)-conjugated lectins (PNA, SBA, HPA, LTA, Con-A, UEA-I, WGA,DBA), and Digoxigenin (DIG)-labelled lectins (MAA,GNA, AAA, SNA) was used with the following objectives: a) to establish the possibility that some lectins may specifically detect apoptotic cells in classical lectin histochemistry, b) to identify which seminiferous epithelial cell types may be identified as apoptotic by these lectins and c) to ascertain the phase of the apoptosis process in which these lectins are positive in the cells of the seminiferous epithelium [55].

In a previous study we found variations in the lectin binding pattern in regressed testes with respect to testes subject a longphotoperiod, especially in spermatogonia and spermatocytes. These changes appear especially in the plasma membrane, and might be related with the apoptosis that occurs in these cells [58]. In the new study the lectins used show affinity for germinal cells in apoptosis, at what stage of cell death they do so and, in which germinal cell types they can be detected.

Various results were obtained in our study: a) the lectins that identified apoptotic cells did so in both spermatids and spermatocytes, although LTA only showed affinity for spermatocytes. Our results suggest that "the residues of Gal $\beta 1,3-G a l N A c a 1, \alpha$-D-mannose, $\mathrm{N}$ acetylgalactosamine or L-fucose in the $\mathrm{N}$-glycoprotein core are involved in apoptosis regardless of the cell type, whereas the L-fucose terminal (Lewis X antigen; LTA)" [55,59] is only involved in the apoptosis of spermatocytes (Figure 1), b) the residues identified by our battery of lectins in apoptotic cells were similar to those found in isolated cell types in apoptosis by other authors: $\beta$-D-galactose and $\alpha$ D-mannose [44,46], L-Fucose (antigen Lewis X) [60] or $\mathrm{N}$ acetylgalactosamine [61] in which the changes we observed in some sugars have been observed in the early stages of apoptosis $[44,46,49,62]$. These carbohydrates could participate in the identification and removal of apoptotic cells by phagocytes (Sertoli cells), based on their recognition by the 'eat me signals' found on the cell membrane [51]. "These phagocytic cells recognized the signals and rapidly phagocytized the apoptotic cells before they were degraded, thus preventing the inflammatory reaction and protecting tissues from the damaging effects of the potentially harmful intracellular contents $[55,61]$, c) the plasma membrane of apoptotic cells was lectin-positive during their early stages, while their cytoplasm was also lectin-positive in later stages. "This may be because the cytoplasm of germ cells undergoes major deterioration during the intermediate stages of apoptosis, when characteristics very similar to necrosis become evident, accompanied by the low-level formation of apoptotic bodies $[55,63]$.

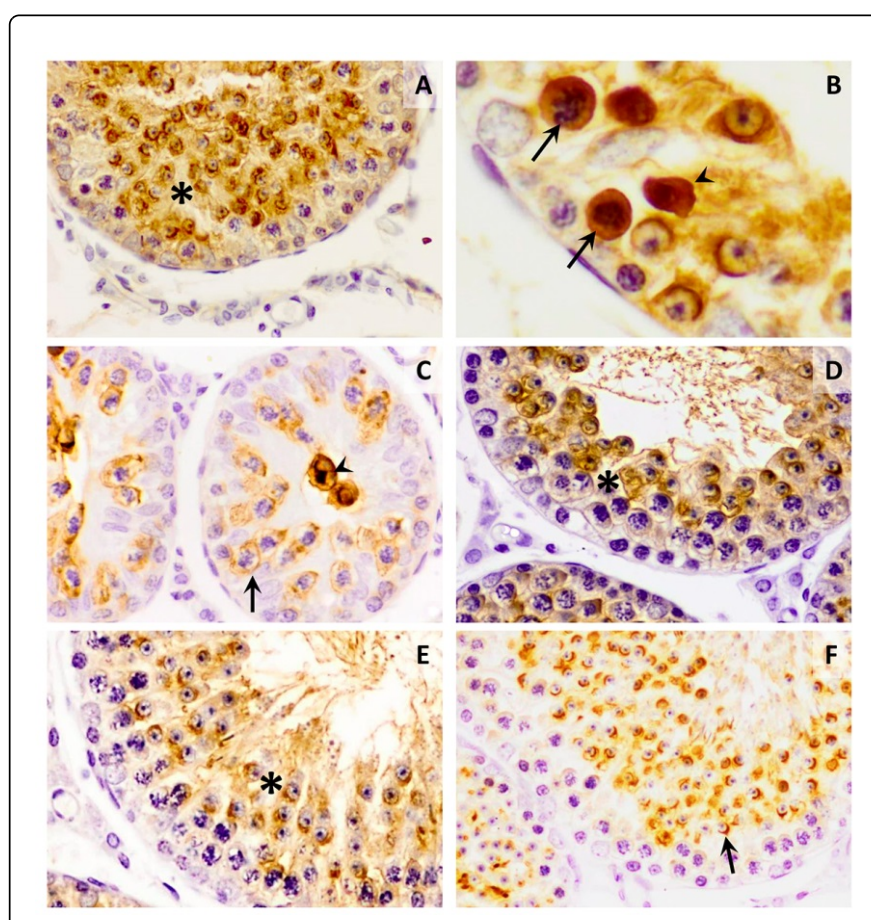

Figure 1: Lectin histochemistry of PNA lectin with affinity by Gal $\beta 1,3-$ GalNAcal in the hamster testis. A) Section of seminiferous tubule in process of regression after short photoperiod. The spermatids show higher affinity for PNA lectin (asterisk).X20. B) With further magnification apoptotic spermatocytes (asterisk) and spermatids (double asterisk) are identified.X60. C) Sections of seminiferous tubules completely regressed. The affinity for the PNA lectin is shown in the plasma membrane of some spermatocytes (arrow) and some round spermatids (double arrow).X20. D) Section of seminiferous tubule in process of initial recrudescence after regression due short photoperiod. The epithelium in this portion of tubule is still in spermatids arrest. The spermatids are highly positives by PNA lectin (asterisk).X40. D) However, other section in recrudescence show portion of tubule with a decrease of both spermatids and spermatocyte in affinity for PNA (asterisk).X20. E) Final recrudescence. The lectin PNA shows affinity in spermatids, especially in its acrosome (arrow).X20.

Degeneration of the cytoplasm may facilitate exposure of numerous carbohydrate residues that are more accessible to these lectins, d) 
Page 5 of 7

"Finally, PNA lectin revealed the presence of Sertoli cells in apoptotic processes and another group of lectins (HPA and SBA) that showed affinity for late spermatid acrosomes were positive within Sertoli cells. Although the Sertoli cell is very stable, it can undergo apoptosis in vitro [64] during post-natal development [65], in hypogonadal mouse [66] or after the administration of certain substances [67]. At the same time, it has been described that other lectins that bind to galactose residues are also positive towards apoptotic Sertoli cells in the spotted ray (Torpedo marmorata)" [55,68].

Therefore, our study, while confirming the usefulness of lectins to identify Sertoli cells undergoing apoptosis in mammals, shows that lectins can also identify their elimination during testicular regression, a fact that has also been observed in our laboratory using TUNEL and transmission electron microscopy [69]. Furthermore, during testicular regression, the Sertoli cell was observed to have a strong phagocytic capacity, which affected whole late spermatids [69]. Table 2 summarize the results most important commented.

\begin{tabular}{|c|c|c|c|}
\hline Authors & $\begin{array}{l}\text { Apoptotic cell } \\
\text { types identified }\end{array}$ & Positive to Lectin & Reference \\
\hline Liguoro, et al., & Spermatoblast & WFA & 68 \\
\hline \multirow{3}{*}{ Seco-Rovira, et al. } & Spermatids & $\begin{array}{l}\text { PNA, GNA, AAA, } \\
\text { HPA, Con-A }\end{array}$ & \multirow{3}{*}{55} \\
\hline & Spermatocytes & $\begin{array}{l}\text { PNA, GNA, AAA, } \\
\text { HPA, LTA, Con-A }\end{array}$ & \\
\hline & Sertoli cells & PNA & \\
\hline
\end{tabular}

Table 2: Bibliography and results related with the identification of apoptotic cells in seminiferous epithelium using lectin histochemistry in histological sections.

In conclusion, our study has shown, for the first time in mammals, that lectin histochemistry could be a useful tool for identifying cells in diverse phases of apoptosis in tissue sections. However, it is necessary to apply lectin histochemistry to other organs that show abundant apoptosis to verify their utility and limitations respect others established apoptosis assays. The use of lectin histochemistry could be a very useful tool for studying apoptosis in a variety of organs and tissues and could become a high spectrum technique for identifying apoptotic cells not only in the initial stages but also at other stages of apoptosis, in normal and pathological situations.

\section{Acknowledgments}

This study was supported by grants 05741/PI/07, 04542/GERM06 and 04543/GERM/06 from the Fundación Séneca, Comunidad Autónoma de la Región de Murcia.

\section{Author Contributions}

Vicente Seco-Rovira involved in the design paper, acquisition, analysis, interpretation of literature and drafting the paper. Esther Beltran-Frutos, Concepcion Ferrer, Jesús Martinez-Hernandez participated in the acquisition and interpretation of literature. Luis M. Pastor participated in all phases of paper elaboration. All authors participated in the revision and corrections of the manuscript and approved the final manuscript.

\section{References}

1. Tabibzadeh S (1995) Signals and molecular pathways involved in apoptosis, with special emphasis on human endometrium. Hum Reprod Update 1: 303-323.

2. Pastor LM, Zuasti A, Ferrer C, Bernal-Manas CM, Morales E, et al. (2011) Proliferation and apoptosis in aged and photoregressed mammalian seminiferous epithelium, with particular attention to rodents and humans. Reprod Domest Anim 46: 155-164.

3. Häcker G (2000) The morphology of apoptosis. Cell Tissue Res 301: 5-17.

4. Kerr JF, Wyllie AH, Currie AR (1972) Apoptosis: a basic biological phenomenon with wide-ranging implications in tissue kinetics. $\mathrm{Br} \mathrm{J}$ Cancer 26: 239-257.

5. Kerr JF (1971) Shrinkage necrosis: a distinct mode of cellular death. J Pathol 105: 13-20.

6. Thompson CB (1995) Apoptosis in the pathogenesis and treatment of disease. Science 267: 1456-1462.

7. Villa P, Kaufmann SH, Earnshaw WC (1997) Caspases and caspase inhibitors. Trends Biochem Sci 22: 388-393.

8. Nuñez G, Benedict MA, Hu Y, Inohara N (1998) Caspases: the proteases of the apoptotic pathway. Oncogene 17: 3237-3245.

9. Grütter MG (2000) Caspases: key players in programmed cell death. Curr Opin Struct Biol 10: 649-655.

10. Takahashi A, Musy PY, Martins LM, Poirier GG, Moyer RW, et al. (1996) CrmA/SPI-2 inhibition of an endogenous ICE-related protease responsible for lamin A cleavage and apoptotic nuclear fragmentation. J Biol Chem 271: 32487-32490.

11. Nakagawa T, Zhu H, Morishima N, Li E, Xu J, et al. (2000) Caspase-12 mediates endoplasmic-reticulum-specific apoptosis and cytotoxicity by amyloid-beta. Nature 403: 98-103.

12. King KL, Cidlowski JA (1998) Cell cycle regulation and apoptosis. Annu Rev Physiol 60: 601-617.

13. Tilly JL, Kowalski KI, Johnson AL, Hsueh AJ (1991) Involvement of apoptosis in ovarian follicular atresia and postovulatory regression. Endocrinology 129: 2799-2801.

14. Morales E, Ferrer C, Zuasti A, Garcia-Borron JC, Canteras M, et al. (2007) Apoptosis and molecular pathways in the seminiferous epithelium of aged and photoinhibited Syrian hamsters (Mesocricetus auratus). J Androl 28: 123-135.

15. Carson DA, Ribeiro JM (1993) Apoptosis and disease. Lancet 341: 1251-1254.

16. Lichtenstein RG, Rabinovich GA (2013) Glycobiology of cell death: when glycans and lectins govern cell fate. Cell Death Differ 20: 976-986.

17. Spicer SS (1993) Advantages of histochemistry for the study of cell biology. Histochem J 25: 531-547.

18. Goldstein IJ, Winter H, Poretz R (1997) Plant lectins:tools for the study of complex carbohidrates. In: Glycoproteins II (Eds Montreuil J, Vliegenthart J, Schachter H). Elsevier, Amsterdam.

19. Sharon N, Lis H (1997) Microbial lectins and their glycoprotein receptors. In: Glycoproteins II (Eds Montreuil J, Vliegenthart J, Schachter H). Elsevier, Amsterdam.

20. Lis H, Sharon N (1998) Lectins: Carbohydrate-Specific Proteins That Mediate Cellular Recognition. Chem Rev 98: 637-674.

21. Naeem A, Saleemuddin M, Khan RH (2007) Glycoprotein targeting and other applications of lectins in biotechnology. Curr Protein Pept Sci 8: 261-271.

22. Sharon N (2007) Lectins: carbohydrate-specific reagents and biological recognition molecules. J Biol Chem 282: 2753-2764.

23. Holgersson J, Gustafson A, Gaunitz S (2009) Bacterial and viral lectins. In: The sugar code. Fundamentals of glycosciences, (Ed Gabius $\mathrm{H}$ ), Wiley, Weinheim.

24. Rudiger H, Gabius H (2009) Plant lectins. In: The sugar code. Fundamentals of glycosciences, (Ed Gabius H), Wiley, Weinheim.

25. Roth J (2011) Lectins for histochemical demonstration of glycans. Histochem Cell Biol 136: 117-130. 
26. Castells MT, Ballesta J, Pastor LM, Madrid JF, Marin JA (1990) Histochemical characterization of glycoconjugates in the epithelium of the extrapulmonary airways of several vertebrates. Histochem J 22: 24-35.

27. Pastor LM, Frutos MJ, Graña L, Ramos D, Gallego-Huidobro J, et al. (1992) Histochemical study of glycoconjugates in the nasal mucosa of the rat and guinea pig. Histochem J 24: 727-736.

28. Pastor LM, Ferran A, Calvo A, Sprekelsen C, Horn R, et al. (1994) Morphological and histochemical study of human submucosal laryngeal glands. Anat Rec 239: 453-467.

29. Kasper M, Singh G (1995) Epithelial lung cell marker: current tools for cell typing. Histol Histopathol 10: 155-169.

30. Perez-Tomas R, Ballesta J, Madrid F.J, Pastor LM, Hernandez F (1990) Histochemical and ultrastructural study of the digestive tract of the tortoise Testudo graeca (Testudines). J Morphol 204: 235-245.

31. Madrid JF, Hernández F, Ballesta J (1997) Characterization of glycoproteins in the epithelial cells of human and other mammalian gallbladder. A review. Microsc Res Tech 38: 616-630.

32. Madrid JF, Leis O, Díaz-Flores L, Sáez FJ, Hernández F (1998) Lectingold localization of fucose residues in human gastric mucosa. J Histochem Cytochem 46: 1311-1320.

33. Calvo A, Pastor LM, Horn R, Pallares J (1995) Histochemical study of glycoconjugates in the epididymis of the hamster (Mesocricetus auratus). Histochem J 27: 670-680.

34. Calvo A, Pastor LM, Bonet S, Pinart E, Ventura M (2000) Characterization of the glycoconjugates of boar testis and epididymis. J Reprod Fertil 120: 325-335.

35. Pinart E, Bonet S, Briz M, Pastor LM, Sancho S, et al. (2001) Lectin affinity of the seminiferous epithelium in healthy and cryptorchid postpubertal boars. Int J Androl 24: 153-164.

36. Badia E, Pinart E, Briz M, Pastor LM, Sancho S, et al. (2005) Lectin histochemistry of the boar bulbourethral glands. Eur J Histochem 49: 131-138.

37. Morales E, Polo LA, Pastor LM, Santamaría L, Calvo A, et al. (2005) Characterization of corpora amylacea glycoconjugates in normal and hyperplastic glands of human prostate. J Mol Histol 36: 235-242.

38. Avilés M, Martínez-Menárguez JA, Castells MT, Madrid JF, Ballesta J (1994) Cytochemical characterization of oligosaccharide side chains of the glycoproteins of rat zona pellucida: an ultrastructural study. Anat Rec 239: 137-149.

39. Avilés M, El-Mestrah M, Jaber L, Castells MT, Ballesta J, et al. (2000) Cytochemical demonstration of modification of carbohydrates in the mouse zona pellucida during folliculogenesis. Histochem Cell Biol 113: 207-219.

40. Pastor LM, Lucas X, Pallares J, Bernal-Mañas CM, Martinez EA, et al. (2008) Characterization of glycoside residues of porcine zona pellucida and ooplasm during follicular development and atresia. Mol Reprod Dev 75: 1473-1483.

41. Roth J, Zuber C, Komminoth P, Sata T, Li WP, et al. (1996) Applications of immunogold and lectin-gold labeling in tumor research and diagnosis. Histochem Cell Biol 106: 131-148.

42. Taatjes DJ, Sobel BE, Budd RC (2008) Morphological and cytochemical determination of cell death by apoptosis. Histochem Cell Biol 129: 33-43.

43. Koopman G, Reutelingsperger CP, Kuijten GA, Keehnen RM, Pals ST, et al. (1994) Annexin V for flow cytometric detection of phosphatidylserine expression on B cells undergoing apoptosis. Blood 84: 1415-1420.

44. Bilyy RO, Antonyuk VO, Stoika RS (2004) Cytochemical study of role of alpha-d-mannose- and beta-d-galactose-containing glycoproteins in apoptosis. J Mol Histol 35: 829-838.

45. Bilyy R, Kit Y, Hellman U, Tryndyak V, Kaminskyy V, et al. (2005) In vivo expression and characteristics of novel alpha-D-mannose-rich glycoprotein markers of apoptotic cells. Cell Biol Int 29: 920-928.

46. Bilyy RO, Stoika RS (2003) Lectinocytochemical detection of apoptotic murine leukemia L1210 cells. Cytometry A 56: 89-95.

47. Bilyy R, Stoika R (2007) Search for novel cell surface markers of apoptotic cells. Autoimmunity 40: 249-253.
48. Batisse C, Marquet J, Greffard A, Fleury-Feith J, Jaurand MC, et al. (2004) Lectin-based three-color flow cytometric approach for studying cell surface glycosylation changes that occur during apoptosis. Cytometry A 62: 81-88.

49. Franz S, Frey B, Sheriff A, Gaipl US, Beer A, et al. (2006) Lectins detect changes of the glycosylation status of plasma membrane constituents during late apoptosis. Cytometry A 69: 230-239.

50. Malagolini N, Chiricolo M, Marini M, Dall'Olio F (2009) Exposure of alpha2,6-sialylated lactosaminic chains marks apoptotic and necrotic death in different cell types. Glycobiology 19: 172-181.

51. Bilyy R, Nemesh L, Antonyuk V, Kit Y, Valchuk I et al. (2009) Apoptosisrelated changes in plasma membrane glycoconjugates of peripheral blood lymphocytes in rheumatoid arthritis. Autoimmunity 42: 334-336.

52. Bilyy RO, Shkandina T, Tomin A, Muñoz LE, Franz S, et al. (2012) Macrophages discriminate glycosylation patterns of apoptotic cellderived microparticles. J Biol Chem 287: 496-503.

53. Azuma Y, Inami Y, Matsumoto K (2002) Alterations in cell surface phosphatidylserine and sugar chains during apoptosis and their timedependent role in phagocytosis by macrophages. Biol Pharm Bull 25: 1277-1281.

54. Bilyy R, Kit Y, Hellman U, Stoika R (2008) AMID: new insights on its intracellular localization and expression at apoptosis. Apoptosis 13: 729-732

55. Seco-Rovira V, Beltrán-Frutos E, Ferrer C, Sánchez-Huertas MM, Madrid JF, et al. (2013) Lectin histochemistry as a tool to identify apoptotic cells in the seminiferous epithelium of Syrian hamster (Mesocricetus auratus) subjected to short photoperiod. Reprod Domest Anim 48: 974-983

56. Sinha Hikim AP, Swerdloff RS (1999) Hormonal and genetic control of germ cell apoptosis in the testis. Rev Reprod 4: 38-47.

57. Boekelheide K, Fleming SL, Johnson KJ, Patel SR, Schoenfeld HA (2000) Role of Sertoli cells in injury-associated testicular germ cell apoptosis. Proc Soc Exp Biol Med 225: 105-115.

58. Pastor LM, Morales E, Polo LA, Calvo A, Pallarés J, et al. (2003) Histochemical study of glycoconjugates in active and photoperiodicallyregressed testis of hamster (Mesocricetus auratus). Acta Histochem 105: $165-173$.

59. Yan L, Wilkins PP, Alvarez-Manilla G, Do SI, Smith DF, et al. (1997) Immobilized Lotus tetragonolobus agglutinin binds oligosaccharides containing the Le(x) determinant. Glycoconj J 14: 45-55.

60. Azuma Y, Kurusu Y, Sato H, Higai K, Matsumoto K (2007) Increased expression of Lewis $\mathrm{X}$ and $\mathrm{Y}$ antigens on the cell surface and FUT 4 mRNA during granzyme B-induced Jurkat cell apoptosis. Biol Pharm Bull 30: 655-660.

61. Falasca L, Bergamini A, Serafino A, Balabaud C, Dini L (1996) Human Kupffer cell recognition and phagocytosis of apoptotic peripheral blood lymphocytes. Exp Cell Res 224: 152-162.

62. Nauta AJ, Raaschou-Jensen N, Roos A, Daha MR, Madsen HO, et al. (2003) Mannose-binding lectin engagement with late apoptotic and necrotic cells. Eur J Immunol 33: 2853-2863.

63. Koji T, Hishikawa Y (2003) Germ cell apoptosis and its molecular trigger in mouse testes. Arch Histol Cytol 66: 1-16.

64. Tesarik J, Guido M, Mendoza C, Greco E (1998) Human spermatogenesis in vitro: respective effects of follicle-stimulating hormone and testosterone on meiosis, spermiogenesis, and Sertoli cell apoptosis. J Clin Endocrinol Metab 83: 4467-4473.

65. Berensztein EB, Sciara MI, Rivarola MA, Belgorosky A (2002). Apoptosis and proliferation of human testicular somatic and germ cells during prepuberty: high rate of testicular growth in newborns mediated by decreased apoptosis. J Clin Endocrinol Metab 87: 5113-5118.

66. Chausiaux OE, Abel MH, Baxter FO, Khaled WT, Ellis PJ, et al. (2008) Hypogonadal mouse, a model to study the effects of the endogenous lack of gonadotropins on apoptosis. Biol Reprod 78: 77-90. 
Citation: Seco-Rovira V, Beltrán-Frutos E, Ferrer C, Martínez-Hernández J, Pastor LM (2015) Identification of Apoptotic Cells by Means of Lectin Histochemistry: State of the Art Review. J Cytol Histol 6: 309. doi:10.4172/2157-7099.1000309

Page 7 of 7

67. Sasso-Cerri E, Miraglia SM (2002) In situ demonstration of both TUNEL-labeled germ cell and Sertoli cell in the cimetidine-treated rats. Histol Histopathol 17: 411-417.

68. Liguoro A, Prisco M, Mennella C, Ricchiari L, Angelini F, et al. (2004) Distribution of terminal sugar residues in the testis of the spotted ray Torpedo marmorata. Mol Reprod Dev 68: 524-530.
69. Seco-Rovira V, Beltrán-Frutos E, Ferrer C, Sáez FJ, Madrid JF, et al. (2014) The death of Sertoli cells and the capacity to phagocytize elongated spermatids during testicular regression due to short photoperiod in Syrian hamster (Mesocricetus auratus). Biol Reprod 90: $1-10$. 